\title{
In-vitro Efficacy of Plant-Extract against Sudden Death Syndrome (wilt) of Soybean caused by Fusarium oxysporum f. sp. virguliforme
}

\author{
S. S. Gote ${ }^{*}$, P. H. Ghante, V. S. Mete, U. A. Asalkar and A. A. Kamble \\ Department of Plant Pathology, College of Agriculture, Badnapur, \\ V.N.M.K.V Parbhani (M.H), India \\ *Corresponding author
}

\begin{abstract}
A B S T R A C T
Keywords

Plant extract,

Fusarium

oxysporum f. sp.

virguliforme, In-

vitro, Soybean

Article Info

Accepted:

20 January 2021

Available Online:

10 February 2021

\section{Introduction}

Soybean [Glycine max (L.) Merrill] is a native of northern China and is the most important legume crop in the world. Soybean is called 'Golden bean'. Soybean plants like many others legumes are capable of fixing and utilizing atmospheric nitrogen through symbiotic relationship with Rhizobium bacterium at the root of the crops.

The crop thus, improves soil fertility and economizes crop production not only for themselves but also for the next crop grown in rotation especially, cereal crops (Nassiuma

and Wasike, 2002) $)^{[5]}$. It has medicinal importance as soya based food helps to control diabetics and melts all kinds of stones in the urinary bladder.

Seeds were primarily used as pulses by the local population and the green and dried vegetative part were used as foliage for cattle. In addition, $100 \mathrm{~g}$ soybean contains $240 \mathrm{mg}$ calcium, $690 \mathrm{mg}$ phosphorous, $11.50 \mathrm{mg}$ iron, 432 calories, $10.50 \mathrm{~g}$ fats and $426 \mathrm{mg}$ vitamins A, B and D (Nagraj, 1995) ${ }^{[4]}$. The major soybean growing countries in the world are United States of America, Brazil, Argentina, China, India and European
\end{abstract}


community (Saxena, 1976) ${ }^{[8]}$.Soybean crop can be attacked by more than 100 pathogens (Sinclair and Schurtleff, 1975) $^{[9]}$. About 35 pathogens were reported to infect soybean in India (Gupta et al., 2001) ${ }^{[3]}$. Fungi, nematodes, viruses, bacteria, and phytoplasmas are known to cause diseases of soybean. The soybean crop is presently suffered due to one of the important disease known as sudden death syndrome. The sudden death syndrome disease is called as wilt of soybean. The soybean wilt is caused by Fusarium oxysporum f. sp. virguliforme (Aoki 2003) $^{[1]}$. Fusarium genus is a soil borne fungus that causes wilt of many crops. In many cases the fungus causing wilt in a particular crop is specific to that crop. In case of soybean, sudden death syndrome caused by the soil borne pathogen $F$. solani f. $\mathrm{sp}$. glycines formerly called Fusarium virguliforme sp. in recent days which was first observed in Arkansas during 1971 (Roy et al., 1997) ${ }^{[7]}$. It can cause great damage, as it may reduce the average yield of soybean by up to 59 per cent (Sinclair and Backman 1989) ${ }^{[10]}$.

\section{Materials and Methods}

Plant based pesticides which are relatively economical, safe and non- hazardous can be successfully used against the plant pathogenic fungi. The following phyto-extracts / botanicals were selected to know their efficacy in inhibition of Fusarium oxysporum f. sp. virguliforme (as virulent one). Antifungal activity of different plant extracts were studied under in-vitro condition. The nine medicinal plant species viz., Neem, Tulsi, Parthenium, Ghaneri, Garlic, Gliricidia, Onion and Drumstick were used to study antifungal activity.

\section{Preparation of phyto-extracts}

Fresh healthy plant parts (leaves/cloves/bulbs/rhizomes) collected from fields were washed with distilled water and air-dried. Each plant extract was crushed in $100 \mathrm{ml}$ of acetone (Garlic and Onion crushed in $100 \mathrm{ml}$ of distilled water volume by volume. The extract was filtered through double layered, muslin cloth and further filtrated through Whatsman No.1 filter paper using funnel and volumetric flasks $(100 \mathrm{ml}$ cap.).

To study the antifungal mechanism of plant extract, the poisoned food technique was used (Nene and Thapliyal, 1982) ${ }^{[6]}$. An appropriate quantity of each plant extract $(100 \%)$ was separately mixed thoroughly with autoclaved and cooled (400C) PDA medium in conical flasks (250 $\mathrm{ml}$ cap.) to obtained desired concentrations of $10 \%$ (10 ml solution mixed with $90 \mathrm{ml}$ molten PDA media). The PDA medium amended separately with plant extracts was then poured $(10 \mathrm{ml} / \mathrm{plate})$ into sterile glass petri plates (90 $\mathrm{mm}$ dia.) and allowed to solidify at room temperature.

After solidification of PDA, all the treatment and control plates were aseptically inoculated by placing in the center a $5 \mathrm{~mm}$ mycelial disc obtained from a week old actively growing pure culture of $F$. oxysporum. Plates containing plain PDA without any botanical extract served as untreated control. For each test botanical extract, three plates / treatment were maintained. All these plates were then incubated at $27 \pm 20 \mathrm{C}$ temperature for a week or till the untreated control plates were fully covered with mycelial growth of the test fungus.

All these plant extracts were evaluated @ 10 $\%$ and observations on radial mycelial growth of the test pathogen were recorded at $24 \mathrm{hrs}$. interval and continued till growth of test pathogen in untreated control plate was fully covered. Per cent inhibition of test pathogen was also calculated by applying the formula given by Vincent, $(1927)^{[13]}$. 
Percent inhibition $(I)=\frac{\mathrm{C}-\mathrm{T}}{\mathrm{C}}$

Where,

$\mathrm{C}=$ Growth of the test fungus in (mm) untreated control plates.

$\mathrm{T}=$ Growth of the test pathogen in $(\mathrm{mm})$ treated plates.

\section{Results and Discussion}

The antifungal activities of eight phytoextracts were assessed at $10 \%$ concentration in the laboratory for evaluation of their efficacy against Fusarium oxysporum f. sp. virguliforme by using poisoned food technique.

Phyto-extract of eight botanicals were evaluated in-vitro (each @ $10 \%$ concentration) against test pathogen and the results obtained on its mycelial growth and inhibition are presented in the Table 1 and depicted in the PLATE X, Fig. 1. Results revealed that all the eight botanical extracts tested were fungaistatic cum antifungal to Fusarium oxysporum f. sp. virguliforme which were significantly reduced mycelial growth and increased inhibition over untreated control (PLATE $X$ and Fig. 1).

Table.1 In vitro evaluation of different plant extracts against Fusarium oxysporum $\mathrm{f}$. sp.

Virguliforme

\begin{tabular}{|c|c|c|c|c|}
\hline \multirow[t]{2}{*}{ Tr. No. } & \multicolumn{2}{|c|}{ Treatments } & \multirow{2}{*}{$\begin{array}{l}\text { Colony Diameter } \\
\text { of pathogen } \\
*(\mathbf{m m})\end{array}$} & \multirow{2}{*}{$\begin{array}{l}\text { Per cent } \\
\text { inhibition }\end{array}$} \\
\hline & Botanical name & Common name & & \\
\hline T1 & Azadirachta indica & Neem & 26.66 & $\begin{array}{c}70.36 \\
(57.01)\end{array}$ \\
\hline $\mathbf{T} 2$ & Oscimum sanctum & Tulsi & 30.66 & $\begin{array}{c}65.92 \\
(54.28)\end{array}$ \\
\hline T3 & Parthenium hysterophorus & Parthenium & 51.00 & $\begin{array}{c}43.32 \\
(41.16)\end{array}$ \\
\hline T4 & Lantana camera & Ghaneri & 40.33 & $\begin{array}{c}55.18 \\
(47.97)\end{array}$ \\
\hline T5 & Allium sativum & Garlic & 22.66 & $\begin{array}{c}74.81 \\
(59.87)\end{array}$ \\
\hline T6 & Gliricidia sepium & Gliricidia & 54.00 & $\begin{array}{c}39.99 \\
(39.22)\end{array}$ \\
\hline T7 & Allium сера & Onion & 36.66 & $\begin{array}{c}59.25 \\
(50.33)\end{array}$ \\
\hline T8 & Moringa oleifera & Drumstick & 56.66 & $\begin{array}{c}38.14 \\
(38.13)\end{array}$ \\
\hline T9 & Control & - & 90.00 & $\begin{array}{c}00.00 \\
(00.00)\end{array}$ \\
\hline & $\mathrm{SE} \pm$ & & 1.19 & 1.25 \\
\hline & CD at $1 \%$ & & 3.56 & 3.75 \\
\hline
\end{tabular}

*Mean of three replications, Figures in parenthesis are arcsine transformed values 
Fig.1 In vitro efficacy of different phyto- extracts against Fusarium oxysporum f. sp. virguliforme
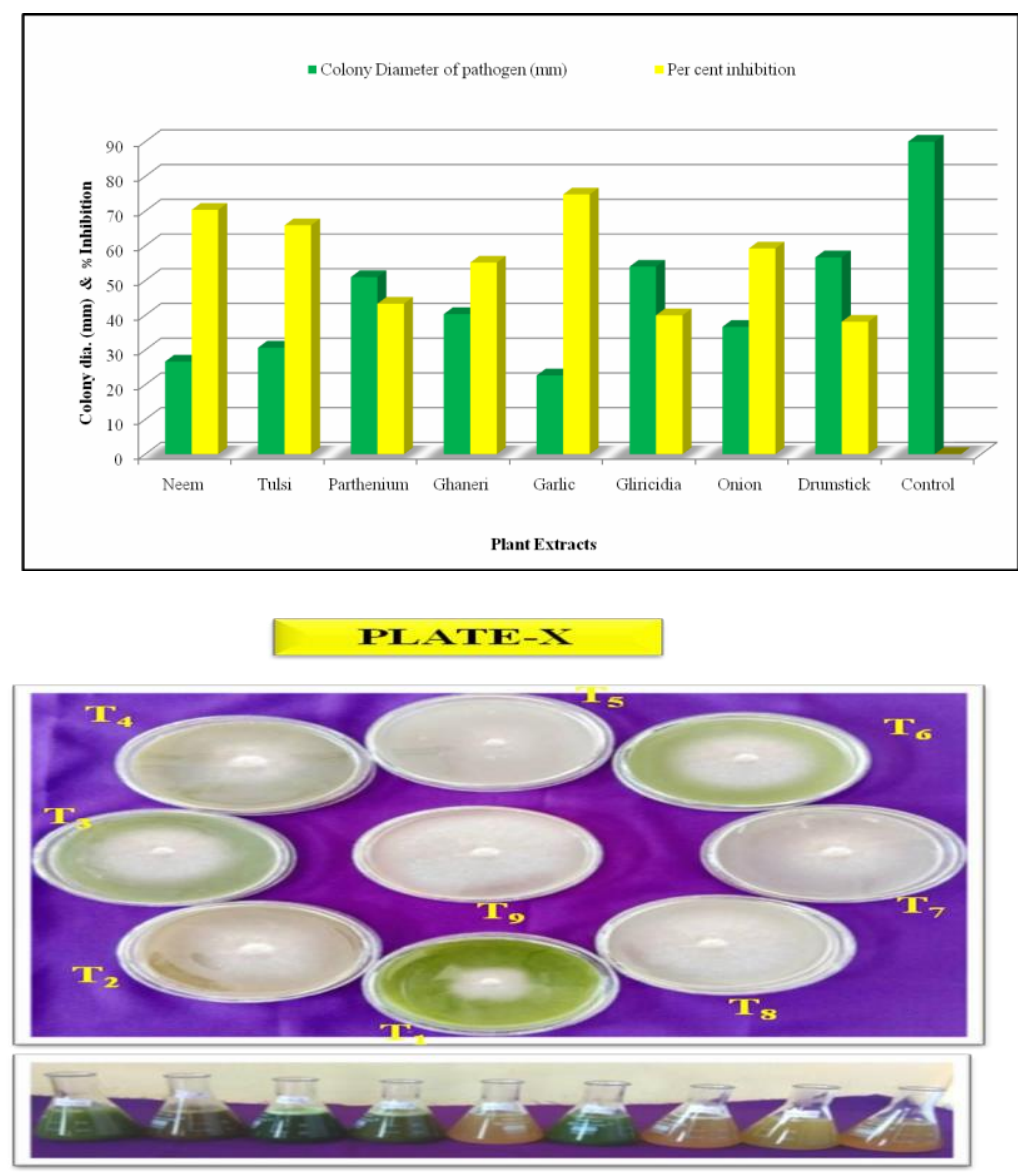

$$
\begin{aligned}
& T_{1}-\text { Neem } \quad T_{5} \text { - Garlic } \\
& T_{2^{-}} \text {Tulsi To- Gliricidia } \\
& \mathbf{T}_{3^{-}} \text {Partherizem } \quad T_{7-} \text { Onion } \\
& \mathbf{T}_{4^{-}} \text {Ghaneri } \\
& T_{\mathbf{s}^{-}} \text {Drumstick }
\end{aligned}
$$

In-virro efficacy of phyto-extracts anainst Fiesarime ovysporzem f. sp. virguliforme.

\section{Mycelial growth}

At 10 per cent concentration, radial mycelial growth of test pathogen was ranged from $22.66 \mathrm{~mm}$ (Garlic clove extract) to $56.66 \mathrm{~mm}$ (Drumstick seed extract) as against $90 \mathrm{~mm}$ in untreated control. However, significantly least mycelial growth was recorded with $22.66 \mathrm{~mm}$ (Garlic clove extract), $26.66 \mathrm{~mm}$ (Neem leaf extract). The next best botanical found was $30.66 \mathrm{~mm}$ (Tulsi leaf extract). It was followed by botanicals viz., $36.66 \mathrm{~mm}$ (Onion bulb extract), $40.33 \mathrm{~mm}$ (Ghaneri leaf extract),
$51.00 \mathrm{~mm}$ (Parthenium leaf extract) and $54.00 \mathrm{~mm}$ (Gliricidia leaf extract). Drumstick seed extract recorded comparatively less effective with maximum mycelial growth of $56.66 \mathrm{~mm}$ and still significantly superior over untreated control (90 mm)

\section{Mycelial growth inhibition}

Results obtained on mycelial growth inhibition of the test pathogen with the botanicals tested at 10 per cent concentrations are presented in the Table 1, depicted in the 
PLATE $X$ and Fig. 1. Result revealed that all the tested botanicals (Plant extract) @ each (10\%) concentration significantly superior and also significantly inhibited mycelial growth of the test pathogen over untreated control.

At 10 per cent concentration, mycelial growth inhibition was ranged from 38.14 per cent (Drumstick seed extract) to 74.81 per cent (Garlic clove extract). However, significantly the highest mycelial growth inhibition was recorded 74.81 per cent by Garlic. It was followed by botanicals viz., Neem leaf extract (70.36\%), Tulsi leaf extract (65.92\%), Onion bulb extract $(59.25 \%)$, Ghaneri leaf extract (55.18\%), Parthenium leaf extract (43.32\%). Gliricidia leaf extract $(39.99 \%)$ and Drumstick seed extract $(38.14 \%)$. The lowest mycelial growth inhibition was recorded with Drumstick seed extract (38.14\%) which was at par with Gliricidia leaf extract (39.99\%), still these two plant extracts significantly superior over the control.

The results of present investigation resembled with the finding of earlier workers viz., Singh et al., $(2017)^{[11]}$ reported that antifungal activity of twelve botanicals including commercial formulations of neem and garlic at $1,2,5$ and 10 per cent concentrations was tested against Fusarium oxysporum under in vitro conditions. Such similar findings mentioned by Dwivedi and Dwivedi. $(2012)^{[2]}$, Suman and Biswas $(2017)^{[12]}$.

\section{References}

1. Aoki, T. (2003). Sudden death syndrome of soybean is caused by two morphologically and phylogenetically distinct species within the Fusarium species complex $F$. virguliforme in North America and F. tucumaniae in South America. Mycologia., 95 (4): 660-684.

2. Dwivedi and Dwivedi (2012). In-vitro bio-efficacy of some selected fungal antagonists against guava wilt pathogen. IOSR Journal of Engineering May., 2(5): 1217-1223.

3. Gupta, C. P., Sharma, A. Dubey, R. C. and Maheshwari, D. K. (2001). Plant growth enhancement and suppression of M. phaseolina causing charcoal rot of peanut of florescent pseudomonas. Ind. J. Exp. Biol., 39: 1318-1321.

4. Nagraj, G. (1995). Quality and utility of oil seeds. Directorate of Oil Research, (ICAR)., Hyderabad.

5. Nassiuma, D. and Wasike, W. (2002). Stability assessment of soybean varieties in Kenya. Afr. Crop Sci. J., 10(2): 139144.

6. Nene, Y. L. and Thapliyal, P. N. (1982). Fungicides in Plant Disease Control. Oxford and IBH Publishing House, New Delhi., 163.

7. 7) Roy, K. W., Rupe, J. C., Hershman, D. E. and Abney, T. S. (1997). Sudden death syndrome of soybean. Plant Dis., 81:1100-1111.

8. Saxena, M. C. (1976). "Soybean in India" in "Expanding the use of soybeans" (Editor: R. M. Goodman) Intsoy Series No. 10, Illinois.

9. Sinclair, J. B. and Schurtleff, M. C. (1975). Compendium of soybean diseases. Amer. Phytopathol. Soc., St Paul, Minnesota.,69.

10. Sinclair, J. B. and Blackman, P. A. (1989). Compendium of soybean diseases Thired. The American phytopathological society str., J-106.

11. Singh, J. K., Kumar, M., Kumar, S., Kumar, A. and Mehta, N. (2017). Inhibitory effect of botanicals on growth and sporulation of Fusarium oxysporum inciting wilt of Chilli (Capsicum annuum L.) Journal of Pharmacognosy and Phytochemistry., 6(5): 2199-2204.

12. Suman, P. and Biswas, M. K. (2017). Eco-Friendly Management of Fusarium 
oxysporum f. sp. ciceri the Causal Agent of Chickpea Wilt Disease under In-vitro Condition. Int.J.Curr.Microbiol.App.Sci., 6(3): 18521858
13. Vincent, J. M. (1927). Distortion of fungal hyphae in the presence of certain inhibitors., 159-180.

\section{How to cite this article:}

Gote, S. S., P. H. Ghante, V. S. Mete, U. A. Asalkar and Kamble, A. A. 2021. In-vitro Efficacy of Plant-Extract against Sudden Death Syndrome (wilt) of Soybean caused by Fusarium oxysporum f. sp. virguliforme. Int.J.Curr.Microbiol.App.Sci. 10(02): 2802-2807. doi: https://doi.org/10.20546/ijcmas.2021.1002.310 